\title{
Studi Komparatif Pengelolaan Pembelajaran pada Homeschooling Primagama dengan Homeschooling Anugrah Bangsa
}

\author{
Yanti Karmila Nengsih \\ Program Studi Pendidikan Luar Sekolah, Fakultas Keguruan dan Ilmu Pendidikan, Universitas \\ Sriwijaya. Jalan Raya Palembang Prabumulih Km 32, Indralaya, Ogan Ilir, Indonesia \\ Email: yantikarmila@gmail.com
}

Received: 12 January 2017; Revised: 8 March 2017; Accepted: 20 March 2017

\begin{abstract}
Abstrak
Tujuan penelitian ini adalah untuk mendeskripsikan dan membandingkan pengelolaan pembelajaran pada homeschooling mengenai aspek perencanaan pembelajaran, pelaksanaan pembelajaran, evaluasi pembelajaran, dan faktor-faktor pendukung dan penghambatnya. Penelitian ini merupakan penelitian komparatif dengan pendekatan deskriptif kualitatif yang dilaksanakan di Daerah Istimewa Yogyakarta (DIY) yang berlokasi di Homeschoolinng Primagama dan Homeschooling ANSA. Hasil penelitian sebagai berikut. (1) Homeschooling Primagama mengidentifikasi kebutuhan peserta didik dengan menggunakan tes psikologi melalui psikolog, sedangkan Homeschooling ANSA melalui wawancara oleh pihak homeschooling. (2) Pelaksanaan pembelajaran di Homeschooling Primagama lebih bersifat semi formal dan terstruktur, sedangkan Homeschooling ANSA lebih bersifat informal. (3) Evaluasi pembelajaran di Homeschooling Primagama terdiri dari aspek kognitif yang dievaluasi oleh tutor/guru, aspek afektif dievaluasi oleh psikolog, sedangkan di Homeschooling ANSA aspek kognitif dan afektif dievaluasi oleh tutor/guru. (4) Faktor pendorong peserta didik dalam belajar di Homeschooling Primagama yaitu motivasi dalam diri peserta didik dan orangtua, sedangkan faktor penghambat yaitu sakit-sakitan, pengaruh gadget, dan online game, sedangkan di Homeschooling ANSA, faktor pendorongnya yaitu untuk meraih cita-cita dan membanggakan orangtua, sedangkan faktor penghambat yaitu ketika peserta didik banyak kegiatan di luar dan masih kurang lengkapnya fasilitas belajar yang tersedia di homeschooling.
\end{abstract}

Kata Kunci: pengelolaan pembelajaran, homeschooling

\section{A Comparative Study of the Teaching Management in Primagama and Anugrah Bangsa Homeschools}

\begin{abstract}
The aims of this study are to describe and compare the teaching management of homeschooling in aspects including: lesson planning, the teaching implementation, teaching evaluation, and the supporting and inhibiting factors of homeschooling. This research was a comparative study, using the descriptive qualitative approach. It was conducted in Primagama and ANSA Homeschools. The results of this study are as follows. (1) Primagama Homeschool identifies learner needs through psychological tests by psychologists, while Homeschool ANSA does it through interviews by the homeschool (2) The implementation of the teaching in Primagama Homeschool is semi formal and structured, while at ANSA Homeschool it is more informal. (3) The evaluation of teaching in Primagama Homeschool consists of cognitive aspects which are evaluated by the teacher, and the are evaluated by a psychologist. At ANSA Homeschool the cognitive and affective aspects are evaluated by the teacher. (4) The supporting factors for learners in learning at Primagama Homeschool include in students and parents, while the inhibiting factors include being sickly, the influence of gadgets, and online games. At ANSA Homeschool the supporting factor is to achieve the ideals and parents pride, while the inhibiting factor is when learners are many outdoor activities and limited incomplete learning facilities.
\end{abstract}

Keywords: learning management, homeschooling 


\section{Jurnal Pendidikan dan Pemberdayaan Masyarakat, 4 (1), March 2017 - 102 \\ Yanti Karmila Nengsih}

\section{PENDAHULUAN}

UUD 1945 Pasal 31 Ayat (1) menyebutkan bahwa, "setiap warga negara berhak mendapatkan pendidikan". Ayat (2) berbunyi, "setiap warga negara wajib mengikuti pendidikan dasar dan pemerintah wajib membiayainya". Bunyi pasal 31 ayat 1 UUD 1945 tersebut menyiratkan makna bahwa setiap anak Indonesia mempunyai hak yang sama untuk mendapatkan pendidikan yang layak. Namun, fakta di lapangan menunjukkan bahwa banyak anak yang memperoleh pengalaman kurang menyenangkan selama belajar di sekolah. Pendekatan sekolah yang legal-formal, struktural, dan terkesan memaksa membuat anak-anak merasa tertekan, sehingga mereka tidak bisa menjalani program belajar mengajar dengan menyenangkan.

UU No. 20 Tahun 2003 tentang Sistem pendidikan Nasional pasal 13 menjelaskan bahwa penyelenggaraan pendidikan dilaksanakan melalui tiga jalur yaitu pendidikan formal, nonformal, dan informal yang saling melengkapi dan memperkaya. Pendidikan Nonformal sebagai bagian integral dari pembangunan pendidikan nasional diselenggarakan untuk menunjang upaya peningkatan mutu sumber daya manusia dalam menghadapi berbagai tantangan guna memenuhi kebutuhan belajar masyarakat yang tidak dapat terlayani oleh jalur pendidikan formal.

Kurang dikenalnya sistem pendidikan pendidikan formal, nonformal, dan informal di kalangan masyarakat Indonesia memunculkan anggapan bahwa pendidikan hanya sebatas di lingkungan sekolah. Pendidikan sekolah formal adalah segala-galanya, sehingga cara apapun akan dilakukan untuk mendapatkan apa yang di sebut dengan bangku sekolah. Sekolah formal dianggap cukup menjadikan orang berpendidikan atau manusia yang seutuhnya. Anggapan ini menjadi salah satu penyebab ketiga lingkungan interaksi pendidikan belum berjalan dengan baik dan sinergis, sehingga belum dapat menciptakan sebuah proses pendidikan yang ideal dengan hasil pendidikan yang berkualitas.

Realitas menunjukkan bahwa kebanyakan proses pendidikan yang terjadi di sekolah formal belum mampu memberikan suasana yang aman, nyaman, menyenangkan bagi peserta didik untuk mengembangkan bakat, minat dan potensi pribadinya secara optimal. Metode konvensional yang diterapkan pada sekolah formal cenderung memperlakukan beragam karakteristik siswa secara seragam. Setiap anak atau peserta didik suka tidak suka, minat tidak minat dalam realitasnya mereka tetap harus mengikuti aturan seragam tersebut dengan jadwal belajar yang sudah terpola dan sistematis lengkap dengan batas waktu yang harus ditempuh secara seragam dengan pelaksanaan ujian yang seragam pula. Rata-rata perbandingan guru dengan murid yang masih terlalu besar 1:40 pada kebanyakan sekolah formal, secara logika juga memungkinkan guru untuk memperhatikan secara lebih dekat bakat dan minat anak secara individual. Banyak peserta didik yang merasa tak tersalurkan bakat, minat dan potensi kecerdasannya (Muhtadi, 2014, p. 3). Suasana pendidikan formal dalam bentuk lembaga sekolah seharusnya memang merupakan ajang belajar yang menggairahkan bagi rasa ingin tahu anak. Namun sayangnya suasana sekolah formal saat ini banyak didominasi oleh pemikiran yang keliru, sehingga justru mengubah anak-anak yang pada dasarnya sangat kreatif menjadi robot-robot kaku yang sangat penurut (Mulyadi, 2007, p. 136).

Potret pelaksanaan sekolah formal semakin ditambah buram dengan banyaknya peristiwa tawuran antar pelajar, terjadinya pergaulan bebas antar pelajar, dan banyaknya pelajar yang terjerat narkoba akhir-akhir ini serta maraknya kasus pelecehan seksual baik di kalangan anak-anak sampai pada remaja. Kebanyakan sekolah formal mengalami kesulitan untuk melakukan kontrol pengawasan dan pengendalian kepada para pelajar dari jeratan negatif arus globalisasi informasi dan modernitas. Selain itu, banyaknya kasus kekerasan yang terjadi pada anak sehingga menimbulkan kekhawatiran tersendiri bagi orang tua. Tahun 2013 hingga bulan oktober tercatat 2.792 kasus, 1.424 kasus kekerasan (52 persen kekerasan seksual anak), 229 tawuran antar pelajar dan lain-lain (www.komnaspa.or.id). 


\section{Jurnal Pendidikan dan Pemberdayaan Masyarakat, 4 (1), March 2017 - 103 \\ Yanti Karmila Nengsih}

Begitu banyaknya permasalahan yang ada di dunia pendidikan formal, membuat sebagian orang tua yang merasa tidak puas dengan output yang dihasilkan oleh sekolah formal, kemudian terdorong untuk mendidik anaknya di rumah. Sekolah rumah atau homeschooling merupakan sebuah pendidikan alternatif. meski dengan resiko orang tua menyediakan banyak waktu dan tenaga. (Simbolon, 2007, p.1)

Sekolah Alternatif merupakan salah satu sekolah nonformal yang bertujuan sebagai penunjang pendidikan formal bagi mereka-mereka yang tidak terlayani di sekolahsekolah formal seperti tinggal kelas karena lambat belajar, nakal atau mengganggu lingkungan (termasuk mereka dalam lembaga pemasyarakatan anak), pasangan suami istri yang masih berusia sekolah, terutama ibuibu belia yang tidak mungkin mengikuti sekolah regular karena harus mengurus anak, korban penyalahgunaan obat terlarang atau minuman keras, korban trauma dalam keluarga, kekerasan atau gelandangan, menderita karena masalah kesehatan, ekonomi, etnis dan budaya, termasuk anak-anak suku terasing, putus sekolah karena berbagi sebab, belum pernah mengenyam program pendidikan sebelumnya, korban bencana alam atau kerusuhan etnis/politis, dan lain sebagainya. Sekolah Alternatif merupakan sekolah yang secara kelembagaan, perencanaan kurikulum, metode pelaksanaan pendidikan, dan metode evaluasinya bersifat alternatif, lahir dari keinginan untuk menghantarkan anak pada persoalan nyata, lembaga dan pengajarannya mampu memberikan pengajaran dengan metode-metode yang lebih inovatif dan kreatif.

Salah satu sekolah alternatif yang berkembang saat ini adalah homeschooling. Sumardiono (2007) menjelaskan bahwa salah satu pengertian homeschooling adalah sebuah keluarga memilih untuk bertanggung jawab sepenuhnya atas proses pendidikan anak dengan berbasis rumah. Meskipun demikian, pendidikan tidak selalu dilakukan orang tua saja. Selain mengajar sendiri, orang tua dapat pula mengundang guru privat, mendaftar anak pada kursus, melibatkan anak pada proses magang, dan sebagainya.
Pada observasi awal yang penulis lakukan di homeschooling Primagama dengan direktur homeschooling Primagama Yogyakarta bapak Kusnanto, sekilas bapak Kusnanto menjelaskan bahwa metode pembelajaran yang diterapkan di homeschooling Primagama ada empat macam yaitu (1) sistem komunitas yang terdiri dari 6-7 orang peserta didik dalam satu kelas, (2) sistem individu atau privat yaitu peserta didik bisa memanggil guru untuk datang ke rumah atau proses pembelajaran bisa juga dilakukan di homeschooling primaga, (3) sistem tanpa pendampingan yaitu peserta didik hanya memberikan uang pangkal kepada pihak homeschooling Primagama yang berkenaan membeli modul atau materi dari homeschooling Primagama untuk selanjutnya peserta didik bebas memilih siapa yang menjadi gurunya, terakhir (4) sistem kelas jauh yaitu menggunakan Skype yaitu pembelajaran dilakukan melalui media internet atau video call.

Sementara itu, observasi awal yang penulis lakukan di lembaga homeschooling ANSA dengan tutor homeschooling ANSA. Diperoleh informasi dari salah satu tutor/ guru bahwa metode yang digunakan pada homeschooling ANSA ada dua yaitu sistem komunitas, disini peserta didik belajar berkelompok dengan bimbingan tutor di homeschooling ANSA dengan jadwal yang sudah diatur, dan sistem distance learning (DL) yaitu peserta didik belajar secara individu di rumah atau dengan memanggil tutor.

Selain data diatas, peneliti juga mendapatkan tambahan data bahwa pada homeschooling Primagama memiliki jumlah peserta didik 215 orang, guru 38 orang dan cabang homeschooling Primagama 20 cabang se-Indonesia. Sedangkan homeschooling ANSA memiliki 60 orang peserta didik, 12 orang guru 7 orang guru ekstrakurikuler dan 4 cabang di Seluruh Indonesia. Dari kedua homeschooling ini, peneliti mendapatkan informasi bahwa sebagian besar peserta didik berasal dari anak yang bermasalah dalam artian peserta didik yang ikut pada homeschooling ini mengalami masalah ketika belajar di sekolah formal sehingga membutuhkan penanganan khusus. Akan tetapi, setelah mengikuti homeschooling, 


\section{Jurnal Pendidikan dan Pemberdayaan Masyarakat, 4 (1), March 2017 - 104 \\ Yanti Karmila Nengsih}

peserta didik yang lulus dari homeschooling ini bisa di terima di Perguruan Tinggi Negeri baik di Indonesia maupun di Luar Negeri, seperti Universitas Gajah Mada, Universitas Padjajaran, Universitas Dusseldorf Jerman dan lain-lain.

Pada homeschooling Primagama dan homeschooling ANSA program pembelajaran yang dilakukan mulai dari SD sampai SMA. Pengelolaan pada penelitian ini bermaksud untuk melihat pengelolaan pembelajaran di homeschooling, dilihat dari perencanaan pembelajaran, pelaksanaan pembelajaran, evaluasi pembelajaran, faktor pendorong dan penghambat pengelolaan pembelajaran di homeschooling. Dalam hal ini, aspek yang ingin dilihat mulai dari perencanaan sampai pada evaluasi pembelajaran adalah komponen-komponen pembelajaran. (Suharsimi Arikunto, 1990, p. 216) menjelaskan bahwa komponen-komponen yang harus diperhatikan dalam perencanaan pembelajaran terdiri atas 6 komponen yaitu peserta didik, pendidik, kurikulum/materi belajar, strategi/ metode, media, dan konteks (lingkungan). Berdasarkan fenomena tersebut, peneliti tertarik untuk meneliti tentang studi komparatif pengelolaan pembelajaran program SMA pada homeschooling Primagama dengan homeschooling Anugrah Bangsa (ANSA) di Yogyakarta.

\section{METODE}

Untuk mendapatkan pemahaman yang mendalam dan menyeluruh terhadap permasalahan komparasi pengelolaan pembelajaran pada homeschooling Primagama dengan homeschooling Anugrah Bangsa (ANSA) di Daerah Istimewa Yogyakarta (DIY), maka penelitian ini menggunakan jenis metode penelitian komparasi (perbandingan) dengan pendekatan deskriptif kualitatif. Metode penelitian perbandingan ialah terdapat berbagai unit sosial makro (makro, budaya, daerah, sistem pendidikan, sistem ekonomi dan periode sejarah) dengan tujuan metode perbandingan ialah membuat pernyataan umum mengenai hubungan logis antar-konsep, pada unit makrososial, konsep-konsep terwakili dalam variabel yang dapat diobservasi (Sutinah, pp.255-256).
Asumsi dasar pendekatan ini adalah bahwa manusia dalam berilmu pengetahuan tidak lepas dari pandangan moralnya, baik pada taraf mengamati, menghimpun data, menganalisis, ataupun dalam membuat kesimpulan. Alasan menggunakan metode ini, karena (1) berorientasi pada proses yang dinamis bukan pada hasil penelitian, (2) memakai logika induktif bukan deduktif, (3) metode ini menyajikan langsung hakikat hubungan peneliti dan responden.

Metode kualitatif merupakan prosedur penelitian yang menghasilkan data-data deskriptif berupa kata-kata tertulis atau lisan dari orang-orang dan perilaku yang dapat diamati. Lebih lanjut juga dikatakan bahwa pendekatan ini diarahkan pada latar dan individu tersebut secara holistic (utuh). Dengan menggunakan penelitian kualitatif peneliti berharap dapat mengungkapkan perbandingan pengelolaan pembelajaran pada homeschooling Primagama dengan homeschooling Anugrah Bangsa (ANSA) secara mendalam melalui beberapa teknik pengumpulan data.

Penelitian kualitatif sebagai jenis penelitian yang temuan-temuannya tidak diperoleh melalui prosedur statistik atau bentuk hitungan. Penelitian kualitatif menekankan pada prosedur analisa non matematis yang diperoleh dari pengamatan, wawancara, melalui dokumen, buku, kaset dan video.

Pendapat tersebut mengandung pengertian bahwa metodologi kualitatif merupakan prosedur penelitian yang menghasilkan data-data deskriptif berupa kata-kata tertulis maupun lisan dari orang-orang atau perilaku yang diteliti. Penelitian kualitatif dimaksudkan untuk melihat perbandingan pengelolaan pembelajaran pada homeschooling Primagama dengan homeschooling Anugrah Bangsa (ANSA) di Yogyakarta.

Subjek penelitian adalah benda, hal atau orang, dimana data untuk variabel penelitian melekat dan yang dipermasalahkan (Arikunto, 2005, p. 99). Adapun subjek dalam penelitian ini yaitu pengelola homeschooling sebanyak 2 orang dengan rincian 1 pengelola homeschooling Primagama dan 1 pengelola homeschooling Anugrah Bangsa (ANSA). Guru 6 orang, dengan rincian 3 guru dari homeschooling Primagama dan 3 


\section{Jurnal Pendidikan dan Pemberdayaan Masyarakat, 4 (1), March 2017 - 105 \\ Yanti Karmila Nengsih}

guru dari homeschooling Anugrah Bangsa (ANSA). Peserta didik 4 orang, dengan rincian 2 peserta didik dari homeschooling Primagama dan 2 peserta didik dari homeschooling Anugrah Bangsa (ANSA).

Adapun tempat diadakannya penelitian ini yaitu pada Homeschooling Primagama, Jalan Langensari 43 Gondokusuman Yogyakarta dan Homeschooling Anugrah Bangsa (ANSA) Jalan Palagan Km. 1o Palagan Asri 3 Ruko No 9. Sedangkan waktu penelitian direncanakan pada Februari-April2015.

Pengumpulan data pada penelitian ini dengan menggunakan teknik wawancara, observasi dan dokumentasi. Keabsahan data menggunakan triangulasi yaitu triangulasi sumber(1) membandingkan data hasil pengamatan dengan hasil wawancara, (2) membandingkan keadaan dengan perspektif seseorang dengan berbagai pendapat atau pandangan seseorang seperti rakyat biasa, orang berpendidikan, dan orang yang memiliki kekuasaan atau pemerintah, dan (3) membandingkan hasil wawancara dengan isi dokumen yang berkaitan. Prosedurnya yaitu peneliti membandingkan antara data hasil observasi/pengamatan, wawancara, dan dokumentasi. Jika hasilnya sesuai antara satu dengan yang lainnya maka keabsahan data dapat dipertanggungjawabkan. Akan tetapi jika hasilnya tidak sesuai maka peneliti menggunakan hasil wawancara sebagai sumber data.

Teknik analisis data kualitatif penelitian ini dilakukan berdasarkan model induktif. Dimana proses pengumpulan yang berlangsung selama pengumpulan data, pasca pengumpulan data serta komponenkomponen analisis data secara interaktif yang saling berhubungan selama dan sesudah pengumpulan data. Analisis yang dikembangkan oleh Miles, Huberman, \& Saldaña (2014, p. 16) menerangkan bahwa analisis terdiri dari tiga alur kegiatan yang terjadi secara bersamaan yaitu: reduksi data, penyajian data, dan penarikan kesimpulan atau verifikasi.

\section{HASIL DAN PEMBAHASAN}

\section{Perencanaan Pembelajaran}

Hasil penelitian pada pengelolaan pembelajaran menjelaskan perbandingan perencanaan pembelajaran program setara SMA pada homeschooling Primagama dengan homeschooling ANSA di DIY.

Tabel 1. Perbandingan Perencanaan Pembelajaran pada Homeschooling Primagama dengan Homeschooling Anugrah Bangsa (ANSA) di DIY

\begin{tabular}{l} 
Homeschooling Primagama \\
\hline Dalam merencanakan pembelajaran di homeschooling \\
Primagama menggunakan silabus dan RPP yang akan digunakan \\
selama satu semester yang telah dirapat oleh sesama tutor/guru \\
mata pelajaran \\
Waktu untuk merencanakan pembelajaran adalah awal semester \\
dan pada akhir semester \\
Jumlah guru di homeschooling Primagama sebanyak 38 orang \\
yang masing-masing mengampu satu mata pelajaran, tetapi guru \\
juga mengajar dari SD sampai SMA
\end{tabular}

Ada 3 orang wali kelas di program setara SMA homeschooling Primagama. Berikut rinciannya: 1 orang wali kelas X dan XI IPA, 1 orang wali kelas X dan XI IPS dan 1 orang wali kelas XI IPA dan IPS

Sebelum peserta didik dinyatakan diterima menjadi peserta didik di homeschooling Primagama. Calon peserta didik harus mengikuti tes DMI yaitu tes minat dan bakat di bagian psikologi untuk mengidentifikasi minat dan bakat peserta didik. Selain itu juga harus melengkapi administrasi untuk mendaftar menjadi peserta didik di Homeschooling Primagama

Materi belajar disusun berdasarkan silabus dan RPP

Homeschooling ANSA

Merencanakan pembelajaran berdasarkan rapat dengan sesama tutor yang ditulis dalam buku agenda dan menyesuaikan dengan bahan ajar

Waktu untuk merencanakan pembelajaran yaitu pada awal semester

Guru di homeschooling ANSA sebanyak 12 orang masing-masing mengampu satu mata pelajaran dan mengajar dari kelas SD sampai SMA dan memiliki 7 orang guru untuk ekstrakurikuler

Hanya ada satu orang wali kelas untuk program setara SMA di homeschooling ANSA

Calon peserta didik membawa persyaratan kelengkapan administrasi dan diwawancarai oleh pihak homeschooling ANSA untuk diterima menjadi peserta didik di homeschooling ANSA

Materi belajar disusun berdasarkan bahan ajar atau buku paket pembelajaran 


\section{Jurnal Pendidikan dan Pemberdayaan Masyarakat, 4 (1), March 2017 - 106 Yanti Karmila Nengsih}

\section{Pelaksanaan Pembelajaran}

Hasil penelitian pada pengelolaan pembelajaran menjelaskan perbandingan pelaksanaan pembelajaran program setara SMA pada homeschooling Primagama dengan homeschooling ANSA di DIY.

\section{Evaluasi Pembelajaran}

Hasil penelitian pada pengelolaan pembelajaran menjelaskan perbandingan evaluasi pembelajaran program setara SMA pada homeschooling Primagama dengan homeschooling ANSA di Daerah Istimewa Yogyakarta.

\section{Faktor Pendorong dan Penghambat Pembelajaran}

Hasil penelitian pada pengelolaan pembelajaran menjelaskan perbandingan faktor pendorong dan penghambat proses pembelajaran program setara SMA pada homeschooling Primagama dengan homeschooling ANSA di DIY.

Tabel 2.Perbandingan Pelaksanaan Pembelajaran pada Homeschooling Primagama dengan Homeschooling Anugrah Bangsa (ANSA) di DIY

\footnotetext{
Homeschooling Primagama

Membuka pelajaran dengan berdoa ketika mata pelajaran yang di ampu adalah jam pertama pada hari tersebut, pada jam kedua belajar tidak melakukan berdoa lagi yaitu langsung pada kegiatan inti, pada jam terakhir maka akan ditutup dengan berdoa

Peserta didik mempresentasikan tugasnya di depan kelas dengan menggunakan in focus

Waktu belajar 1 jam pada masing-masing mata pelajaran

Metode belajar yang digunakan tergantung gurunya dan materi belajar, ada menggunakan power point untuk presentasi, ceramah dan diskusi yang disesuaikan dengan kebutuhan peserta didik

Media pembelajaran menggunakan media pembelajaran yang ada seperti papan tulis, laptop, in focus, untuk ptaktiknya di laboratorium dan menggunakan alat peraga Sumber belajar bermacam-macam, buku paket, jurnal, power point dari internet dan power point yang dibuat oleh tutor/gurui, modul atau hand out
}

\section{Homeschooling ANSA}

Setiap membuka pelajaran dilakukan dengan berdoa

Tutor/guru menerangkan materi pelajaran

Waktu belajar 2 jam pada masing-masing mata pelajaran

Metode belajarnya ceramah, diskusi, belajar di kebun pintar atau tutor/guru lebih banyak melakukan improvisasi sesuai dengan kondisi peserta didiknya Media pembelajaran menggunakan media yang tersedia disekitar homeschooling, seperti sendok dan lain sebagainya

Sumber belajar buku, modul dan materi yang diambil dari internet

Tabel 3. Perbandingan Evaluasi Pembelajaran pada Homeschooling Primagama dengan Homeschooling Anugrah Bangsa (ANSA) di Daerah Istimewa Yogyakarta

\section{Homeschooling Primagama}

Aspek yang di evaluasi oleh tutor/guru adalah kognitif sementara afektifnya dievaluasi oleh bagian psikologi melalui kegiatan pengembangan diri

Tujuan dilakukan evaluasi, laporan bagi guru, peserta didik dan orangtua. Sehingga bisa melihat perkembangan belajar peserta didik

Bentuk evaluasi berupa penugasan/PR, latihan soal, ulangan harian, ujian mid semester, ujian akhir semester dan kegiatan pengembangan diri dari bagian psikologi Ada yang tidak naik kelas dengan sistem remedial untuk menuntaskan mata pelajaran yang belum tuntas tapi masih bisa mengikuti kelas selanjutnya

Setiap anak yang mau tamat dari homeschooling Primagama mengikuti Ujian Nasional (UN) yang dilakukan di Yogyakarta

\section{Homeschooling ANSA}

Tutor/guru mengevaluasi aspek kognitif dan afektif peserta didik

Tujuan dilakukan evaluasi untuk mengetahui perkembangan belajar peserta didik

Bentuk evaluasi yaitu latihan soal, ulangan harian, ujian mid semester dan ujian akhir semester

Ada ketika memang tidak bisa dinaikkan kasus ini terjadi pada peserta didik yang masih SD

Setiap anak yang mau tamat dari ANSA homeschooling mengikuti Ujian Nasional (UN) yang dilakukan di Semarang 


\section{Jurnal Pendidikan dan Pemberdayaan Masyarakat, 4 (1), March 2017 - 107 Yanti Karmila Nengsih}

Tabel 4. Perbandingan Faktor Pendorong dan Penghambat Pembelajaran pada Homeschooling Primagama dengan Homeschooling Anugrah Bangsa (ANSA) di DIY

\begin{tabular}{l} 
Homeschooling Primagama \\
\hline Faktor internal yang mendukung proses belajar \\
peserta didik adalah motivasi dari diri mereka \\
sendiri serta pembelajaran di homeschooling yang \\
sesuai dengan apa yang peserta didik butuhkan \\
Faktor internal yang menghambat peserta didik \\
dalam belajar adalah rasa malas dan ketika sibuk \\
dengan banyak kegiatan di luar
\end{tabular}

Faktor eksternal yang mendukung adalah perhatian orangtua terhadap pendidikan anaknya serta pelajaran yang sesuai dengan kebutuhan anak dan lingkungan homeschooling yang nyaman untuk belajar

Faktor ekternal yang menghambat yaitu sakit dan pengaruh keasyikan menggunakan gadget seperti game online

\section{Pembahasan}

Perencanaan Pembelajaran

Proses perencanaan pembelajaran pada program setara SMA di homeschooling Primagama selalu dilakukan setiap akhir semester atau sebelum semester baru akan di mulai. Para tutor/guru sangat berperan penting dalam merencanakan apa yang akan dipelajari peserta didik selama satu semester ke depannya. Namun walaupun tutor/guru adalah tokoh utama dalam merencanakan pembelajaran, akan tetapi para tutor/guru selalu mengedepankan kepentingan peserta didik dan merencanakan pembelajaran sesuai dengan kebutuhan peserta didik. Menurut Sudjana (2001, p. 211).

Kebutuhan belajar perlu diidentifikasi melalui pendekatan perorangan. Identifikasi ini dilakukan dengan menggunakan instrument yang cocok sehingga dapat mengungkap informasi yang dinyatakan oleh setiap individu yang merasakan kebutuhan belajar. Instrument itu antara lain adalah pedoman wawancara, angket, dan kartu SKBM (Sumber dan Kebutuhan Belajar Masyarakat).

Pada homeschooling Primagama setiap calon peserta didik yang mendaftar untuk sekolah di homeschooling Primagama akan

\section{Homeschooling ANSA}

Faktor internal yang mendukung proses belajar peserta didik adalah keinginan peserta didik dalam meraih mimpi-mimpinya

Faktor internal yang menghambat peserta didik dan tutor dalam proses pembelajaran adalah ketika peserta didik malas untuk ke sekolah dan tidak ada kabar, peserta didik yang sibuk dengan kegiatannya di luar, serta tutor/guru yang kesulitan dalam membagi waktu dalam mengajar

Faktor eksternal yang mendukung adalah orangtua, tempat belajar yang dirasa nyaman oleh peserta didik dan waktu belajar yang fleksibel

Faktor ekternal yang menghambat adalah pengaruh game online, HP atau gadget dan masih kurangnya fasilitas belajar di homeschooling

mendapati fasilitas psikologi yang mana bagian psikologi akan mengidentifikasi kebutuhan calon peserta didik serta melihat karakter calon peserta didik, sehingga ketika calon peserta didik diterima untuk bersekolah di homeschooling Primagama, pendekatan dan penanganan yang diberikan sesuai dengan kebutuhan peserta didik.

Pada homeschooling Primagama penjurusan dilakukan ketika peserta didik berada di kelas $\mathrm{X}$ yaitu peserta didik bisa memilih jurusan IPA atau IPS sesuai dengan bakat dan minat yang mereka miliki. Tujuan dilakukan penjurusan pada kelas $\mathrm{X}$ agar pembelajaran yang diberikan sesuai dengan kebutuhan dan lebih terfokus untuk mengembangkan bakat dan minat yang dimiliki oleh peserta didik.

Perencanaan pembelajaran di homeschooling ANSA dilakukan sebelum semester baru dimulai. Pihak yang terlibat dalam merumuskan atau merencanakan pembelajaran untuk satu semester yang akan datang hanya para tutor/guru mata pelajaran. Sedangkan para orangtua untuk mengontrol perkembangan pembelajaran anaknya ketika berada di rumah, sementara itu lingkungan masyarakat memfasilitasi peserta didik ketika belajar di masyarakat serta menjadi sumber informasi bagi peserta didik. 


\section{Jurnal Pendidikan dan Pemberdayaan Masyarakat, 4 (1), March 2017 - 108 \\ Yanti Karmila Nengsih}

Penentuan materi atau topik bahasan pelajaran dalam perencanaan pembelajaran pada program setara SMA di homeschooling ANSA dilakukan sepenuhnya oleh tutor/ guru. Pada homeschooling ANSA penjurusan dilakukan ketika peserta didik telah menginjak kelas XI. Jurusan yang bisa dipilih oleh peserta didik IPA atau IPS. Ketika peserta didik berasa di kelas $\mathrm{X}$, semua mata pelajaran IPA dan IPS yang di UN kan dipelajari oleh peserta didik. Namun pada prinsipnya ANSA homeschooling tetap memberikan palajaran sesuai dengan kebutuhan peserta didik walaupun dalam belajar seorang tutor sering melakukan improvisasi baik metode belajar maupun media belajar yang digunakan agar peserta didik merasa senang dan nyaman dalam mengikuti pembelajaran serta jadwal pembelajaran yang lebih fleksibel. Peran tutor/guru pada homeschooling ANSA yaitu sebagai tutor/guru yang mendampingi serta memfasilitasi peserta didik dalam belajar.

Pihak-pihak yang terlibat dalam perencanaan pembelajaran pada program setara SMA di homeschooling ANSA hanya tutor/ guru. Semua mengenai pembelajaran diatur oleh tutor/guru yang mana selama satu semester tersebut tutor/guru telah merencanakan apa-apa saja materi yang akan diberikan kepada peserta didik. Setiap tutor/guru bertanggung jawab penuh terhadap mata pelajaran yang mereka ampu dan merencanakan topik-topik yang akan dibahas selama satu semester. Perencanaan pembelajaran di homeschooling ANSA para tutor/guru tidak menuangkan perencanaan pembelajaran dalam bentuk silabus atau RPP, namun dituliskan dalam buku perencanaan pembelajaran atau buku agenda selama satu semester. Hal tersebut dibahas dalam rapat sebelum semester baru dimulai tentang materi apa saja yang akan diberikan kepada peserta didik selama satu semester pada masingmasing mata pelajaran, namun juga diadakan pertemuan minimal 2 kali dalam satu bulan untuk membahas peserta didik yang mengalami kendala atau masalah dalam belajar dan sama-sama dicarikan solusi yang tepat untuk mengatasi masalah peserta didik.

\section{Pelaksanaan Pembelajaran}

Pelaksanaan pembelajaran pada program setara SMA di homeschooling Primagama menggunakan prinsip membebaskan, ditunjukkan dengan tidak adanya seragam, setiap anak memiliki jadwal belajar yang berbeda, namun pada program komunitas anak diberi waktu belajar 3 kali dalam seminggu dan disepakati oleh setiap siswa. Akan tetapi peserta didik juga boleh mengambil jadwal 2 kali seminggu dengan memadatkan mata pelajaran, berdiskusi setiap anak serta disetujui oleh tutor/guru yang akan mengajar. Proses pembelajaran di lakukan dalam kelas dengan jumlah peserta didik maksimal 5 orang, namun tidak semua anak bisa hadir dalam mengikuti proses belajar terkadang hanya tiga atau dua orang peserta didik yang hadir bahkan hanya ada satu orang peserta didik yang bisa hadir. Akan tetapi proses pembelajaran tetap dilanjutkan.

Untuk topik pembelajaran telah disiapkan oleh tutor/guru mata pelajaran yang bersangkutan. Kondisi di dalam kelas dibuat senyaman mungkin agar peserta didik merasa betah belajar dan tidak membosankan. Komunikasi yang dibangun antara peserta didik dan tutor/guru adalah rasa bersahabat namun masih menjunjung norma dan saling menghargai. Proses pembelajaran di homeschooling Primagama dimulai dengan berdoa, menjelaskan materi belajar, dan diakhiri dengan berdoa kembali. Namun hal tersebut tidak dilakukan pada setiap mata pelajaran karena apabila dalam satu hari ada 3 mata pelajaran di homeschooling Primagama maka jam pertama di buka dengan berdoa dan belum di tutup dengan doa ketika sudah selesai, pada jam kedua langsung kepada materi belajar tanpa di buka dengan berdoa dan tidak pula ditutup dengan doa dan pada jam ketiga atau jam terakhir tidak dibuka dengan berdoa, langsung pada materi belajar tetapi pada akhir penutupan pembelajaran ditutup kembali dengan berdoa.

Metode belajar yang digunakan oleh tutor/guru bervariasi seperti ada metode ceramah, diskusi, presentasi dan lain sebagainya. Selain itu, tutor/guru juga sering melakukan improvisasi baik metode maupun 


\section{Jurnal Pendidikan dan Pemberdayaan Masyarakat, 4 (1), March 2017 - 109 \\ Yanti Karmila Nengsih}

media pembelajaran yang digunakan dalam menyampaikan materi pembelajaran agar peserta didik lebih memahami apa yang diajarkan oleh tutor/guru. Proses pembelajaran di homeschooling Primagama sangat mengedepankan rasa senang dan nyaman bagi peserta didik dalam proses pembelajaran, hal tersebut bisa terlihat dari cara tutor/guru yang berusaha berteman atau bersabahat dengan siswa.

Pada prinsipnya pelaksanaan pembelajaran pada program setara SMA di homeschooling ANSA lebih membebaskan para siswa. Hal tersebut dapat dilihat dengan tidak adanya seragam sekolah asalkan peserta didik berpakaian rapi dan sopan, waktu belajar yang fleksibel yang tidak mengharuskan peserta didik masuk setiap hari ke sekolah. Penyelenggaraan program dan proses pembelajaran dalam pendidikan luar sekolah dijiwai dengan prinsip pendidikan nasional yang telah dikemukan oleh Ki Hajar Dewantara (dalam Sudjana, 2001, p. 168).

Ada tiga prinsip yaitu Tut Wuri Handayani, Ing Madya Mangun Karsa, dan Ing Ngarsa Sung Tulada. Prinsip tut wuri handayani mengutamakan pendidikan yang berpusat pada dan didasarkan atas kepentingan peserta didik, serta menitikberatkan pada kegiatan belajar dari pada kegiatan mengajar peserta didik. Prinsip kedua, ing madya mangun karsa, memberi arah bahwa program pendidikan dan proses pembelajarannya dilaksanakan oleh pendidik bersama peserta didik. Prinsip ing ngarso sung tulodo menjelaskan bahwa pendidik menjadi pusat panutan bagi peserta didik.

Proses pembelajaran di homeschooling ANSA, setiap peserta didik bebas berkreasi dengan apa yang menjadi bakat dan minat mereka. Homeschooling ANSA menyediakan program ekstrakurikuler, dimana peserta didik bisa mengembangkan sesuai dengan apa yang mereka minati. Pelaksanaan pembelajaran di homeschooling ANSA di lakukan sesuai dengan kebutuhan peserta didik dan lebih terfokus karena jumlah peserta didik yang lebih sedikit dari pendidikan formal.

Homeschooling ANSA juga menyediakan tempat yang nyaman bagi peserta didik untuk belajar, seperti tersedianya AC di setiap ruangan dan ruangan yang memadai bagi peserta didik untuk belajar. Pada kelas komunitas pada program setara SMA di homeschooling ANSA jumlah peserta didik dibatasi maksimal 5 orang anak dalam satu kelas, anak diklasifikasikan sesuai dengan jurusannya untuk kelas XI dan XII.

Menurut Sihombing (1999, p. 37) mengungkapkan tentang proses pembelajaran pada pendidikan luar sekolah bahwa

Proses belajar dapat terjadi dimana saja, tanpa mengenal batas geografis, tempat, waktu dan usia. Belajar dapat dilaksanakan kapan saja dan bersumber dari apa saja yang memungkinkan memberi makna pada kehidupan seseorang atau warga belajar. Orang mampu belajar dari alam, binatang, tumbuhan, dan orang lain.

Metode pembelajaran yang digunakan pada program setara SMA di homeschooling ANSA yaitu tergantung kepintaran seorang tutor/guru dalam mengembangkan metode belajar yang menarik bagi peserta didik karena setiap tutor/guru mempunyai cara yang unik dan bebas dalam mengimprovisasi sebuah metode maupun media pembelajaran yang menarik sehingga pelajaran mudah dipahami oleh peserta didik. Tutor/guru di homeschooling ANSA dalam proses pelaksanaan pembelajaran ada yang dilakukan di dalam kelas dengan tatap muka, ada juga dilakukan di lingkungan masyakarat seperti kegiatan mengobservasi tatanan kehidupan di masyarakat, proses pembelajaran praktik seperti melakukan kunjungan ke lokasi atau tempat-tempat yang memiliki nikai pelajaran seperti museum dan tempat bersejarah lainnya. Selain itu, para tutor/guru juga sering mengajak peserta didik untuk belajar di kebun pintar milik homeschooling ANSA, yang berada di sekitaran homeschooling ANSA.

Setiap peserta didik memiliki keunikan tersendiri, oleh karena itu dalam proses pembelajaran selalu ditanamkan bahwa pemahaman bukan hafalan-hafalan kecuali mata pelajaran yang mengharuskan peserta didik untuk menghafal. Peserta didik juga disarankan untuk mengetahui pelajaran yang mereka pelajari agar tidak menelan 


\section{Jurnal Pendidikan dan Pemberdayaan Masyarakat, 4 (1), March 2017 - 110 \\ Yanti Karmila Nengsih}

pengetahuan secara mentah-mentah. Pemilihan materi pelajaran berdasarkan buku wajib yang pada setiap pertemuannya dilakukan secara urut.

\section{Evaluasi Pembelajaran}

Evaluasi pembelajaran pada program setara SMA di homeschooling Primagama berupa pemberian tugas harian, latihan-latihan soal, ulangan persub bab mata pelajaran, ujian tengah semester dan ujian akhir semester. Hal tersebut merupakan evaluasi dalam aspek kognitif, selain itu evaluasi juga dilakukan pada aspek afektif atau tingkah laku peserta didik, namun evaluasi pada aspek ini hanya berupa pengamatan para tutor/guru dalam interaksi keseharian antara tutor/guru dengan peserta didik baik dalam kelas maupun di lingkungan homeschooling. Untuk yang lebih berwenang dalam mengevaluasi afektif peserta didik adalah bidang psikologi. Evaluasi dilakukan melalui program pengembangan diri, hasil evaluasi dari bidang psikologi diberikan kepada tutor/ guru wali kelas. Evaluasi yang dilakukan tersebut dituangkan dalam rapor yang dibagikan pada setiap pertengahan semester dan akhir semester.

Evaluasi pada program setara SMA di homeschooling ANSA juga mengenal jenis evaluasi sumatif yaitu dalam bentuk ujian mid semester dan ujian akhir semester. Aspek yang dievaluasi adalah aspek kognitif dan afektif, kedua aspek tersebut dievaluasi oleh tutor/guru pada masing-masing mata pelajaran. Penghargaan yang diberikan kepada peserta didik tidak didasarkan pada nilai-nilai yang diciptakan karena keberhasilan dan kesuksesan yang mereka raih melalui rapor. Akan tetapi lebih kepada penghargaan secara positif dan total yang didasarkan pada pengakuan atas keberadaan diri mereka sehingga mereka merasa merdeka dan tidak berkenan dengan pelajaran.

Kecerdasan peserta didik tidak diukur dengan nilai (kecerdasan intelektual) tetapi sejauh mana tingkat emosional dan kecerdasan religinya, sehingga muncul semangat kebersamaan antar peserta didik, antar peserta didik dengan tutor/guru dan rasa hormat peserta didik kepada kepala sekolah, orangtua dan masyarakat yang ada disekitar mereka. Persaingan pun tidak lagi berupa persaingan yang saling menjatuhkan. Kualitas peserta didik tidak diukur dengan membandingkan satu peserta didik dengan peserta didik lainnya, tetapi dari bertambahnya pengetahuan yang dimiliki. Percayaan diri peserta didik selaku subyek didik dipupuk setiap hari melalui pendampingan dengan tidak menghakimi kekurangan dan menilai peserta didik itu pintar dan bodoh. Akan tetapi menghargai setiap apa yang mereka lakukan, secara tidak langsung kepercayaan diri peserta didikakan tumbuh dan keberanian untuk melakukan inovasi-inovasi akan tumbuh melalui proses belajar maupun dilakukan secara kelompok atau secara belajar mandiri.

\section{Faktor Pendorong dan Penghambat Proses Pembelajaran}

Faktor pendorong pembelajaran pada program setara SMA di homeschooling Primagama salah satunya adalah jam pembelajaran yang fleksibel, sehingga peserta didik bisa memilih jam pelajaran yang sesuai dengan kesibukan mereka.Salah satu contoh faktor eksternal yang menghambat proses pembelajaran adalah ketika peserta didik mulai sibuk dengan dunia mereka sendiri, sibuk dengan kegiatan mereka di luar, dan sibuk bermain gadget.Selain itu, faktor internal yang mempengaruhi minat belajar peserta didik di homeschooling Primagama yaitu peserta didik merasa nyaman berada di sekolah dengan guru yang bersahabat dan mengerti dengan apa yang mereka butuhkan. Faktor internal dalam diri peserta didik yang memiliki cita-cita yang ingin mereka raih di masa depan, misalnya mereka pengen jadi dokter, bisa kuliah di luar negeri dan lain sebagainya, mau tidak mau mereka akan berusaha keras untuk belajar agar mimpimimpinya tercapai.

Faktor pendorong pembelajaran dalam program setara SMA di homeschooling ANSA suasana sekolah yang nyaman dan terbuka bagi peserta didik dalam mengekpresikan diri. Selain peserta didik sudah merasa nyaman dengan lingkungan sekolah di homeschooling ANSA, hal tersebut menumbuhkan minat belajar pada peserta didik. Faktor eksternal yang mendorong peserta 


\section{Jurnal Pendidikan dan Pemberdayaan Masyarakat, 4 (1), March 2017 - 111}

Yanti Karmila Nengsih

didik untuk giat belajar yaitu dukungan orangtua dan orang-orang terdekat peserta didik yang membuat peserta didik punya mimpi yang besar di masa depan dan membuat mereka semangat dalam meraih mimpi-mimpinya.

Selain faktor pendorong juga ada faktor penghambat bagi peserta didik. Faktor internal yang menghambat peserta didik dalam belajar yaitu pengaruh dari perkembangan teknologi seperti gadget, ketika peserta didik sibuk dengan gadget membuat minat belajarnya menurun dan menimbulkan rasa malas, game online dan kegiatan lain yang membuat peserta didik sibuk dengan dunianya sendiri. Faktor eksternal yang menghambat peserta didik untuk belajar yaitu masih ada kekurangan fasilitas belajar di homeschooling ANSA seperti laboratorium praktik yang masih belum lengkap, koleksi perpustakaan yang masih kurang untuk menunjang proses belajar peserta didik di homeschooling ANSA, akan tetapi hal itu tidak terlalu berpengaruh karena peserta didik juga bisa menambah pelajaran di luar jam pelajaran di homeschooling dan kemampuan ekonomi orangtua peserta didik yang rata-rata menengah ke atas juga bisa mengatasi masalah tersebut dengan orangtua menyediakan fasilitas belajar yang lengkap di rumah.

\section{SIMPULAN DAN SARAN}

\section{Simpulan}

Perencanaan pembelajaran dari dua homeschooling di Yogyakarta dilaksanakan oleh para tutor/guru. Perencanaan dilakukan pada setiap akhir semester dan pada awal semester baru. Pada homeschooling Primagama, perencanaan pembelajaran dituangkan dalam bentuk silabus dan RPP yang akan dilaksanakan dalam satu semester. Pada homeschooling Anugrah Bangsa (ANSA) perencanaan pembelajaran dilakukan disetiap awal semester yang dituangkan dalam buku agenda pengajaran atau buku hasil rapat para tutor/guru, untuk pelaksanaan pembelajarannya guru mata pelajaran bebas untuk mengimprovisasi bentuk pembelajaran yang disesuaikan dengan kurikulum.
Proses pelaksanaan pembelajaran pada homeschooling Primagama dan homeschooling ANSA sudah bisa dikatakan efektif karena sudah membuat dan melaksanakan lengkap dengan elemen-elemennya seperti media pembelajaran, metode atau strategi pembelajaran, pengelolaan kelas, waktu belajar yang fleksibel dibandingkan dengan sekolah formal. Tutor/guru pada homeschooling bebas dalam menggunakan metode, media pengajaran, dan pendekatan yang mampu memberdayakan, meningkatkan efektifitas pembelajaran di kelas atau di luar kelas. Pada proses pelaksanaan suasana belajar dan komunikasi yang di bangun di dalam kelas sangatlah bersahabat dan tidak ada jarak antara peserta didik dengan tutor/guru.

Evaluasi pembelajaran yang dilakukan di homeschooling Primagama yaitu pada aspek kognitif dievaluasi oleh tutor/guru sementara aspek afektif dievaluasi oleh bagian psikologi. Homeschooling ANSA pada aspek kognitif dan afektif peserta didik dievaluasi oleh tutor/guru. Tutor/guru tidak terlalu menitikberatkan kepada hasil atau nilai yang dicapai oleh peserta didik namun lebih kepada pengembangan diri dan perubahan ke arah yang lebih positif seperti awalnya peserta didik tidak tahu menjadi tahu, dari tidak rajin ke sekolah menjadi lebih rajin ke sekolah.

Faktor-faktor yang dapat mendorong diri peserta didik secara internal pada kedua homeschooling adalah motivasi yang kuat dalam diri mereka sendiri untuk belajar sementara faktor yang mendorong dari eksternal adalah perhatian orangtua. Faktorfaktor internal yang menghambat peserta didik dalam proses belajar di program setara SMA di kedua homeschooling yaitu ketika peserta didik telah merasa malas dan asyik dengan dunia mereka, banyak kegiatan di luar homeschooling. Sementara itu, faktor eksternal yang menghambat peserta didik dalam proses belajar adalah adanya pengaruh ketergantungan menggunakan gadget, kecanduan game online, sakit, masih kurangnya sarana dan prasarana yang menunjang proses pembelajaran di homeschooling. 


\section{Jurnal Pendidikan dan Pemberdayaan Masyarakat, 4 (1), March 2017 - 112 Yanti Karmila Nengsih}

\section{Saran}

Bagi pihak lembaga, diharapkan: (1) Homeschooling ANSA harus lebih memperhatikan penyusunan perencanaan pembelajaran dengan pengembangan kurikulum KTSP dan lebih mensinkronkan lagi dengan kebutuhan peserta didik; (2) Memperhatikan pelaksanaan pembelajaran yang dilakukan di dalam kelas, laboratorium maupun di masyarakat sehingga dalam menjalankan tugas, perbaikan secara terus menerus dan keterlibatan semua pihak maka diharapkan membawa perubahan serta lebih meningkatkan lagi kualitas sumber belajar, media belajar dan melengkapi semua fasilitas yang dibutuhkan oleh peserta didik seperti memperbanyak buku bacaan atau buku referensi belajar untuk peserta didik di setiap bidang mata pelajaran.

Bagi Dinas Pendidikan Kabupaten/ Kota, diharapkan Guna meningkatkan mutu pendidikan di Indonesia diharapkan pemerintah juga memperhatikan perkembangan pendidikan nonformal dan informal agat ketiga ranah pendidikan yaitu formal, nonformal dan informal bisa berjalan beriringan, saling melengkapi untuk mencapai pendidikan indonesia yang berkualitas. Diharapkan pemerintah mampu berkerjasama dengan pendidikan alternatif yang ada di Indonesia terkhusus pendidikan homeschooling untuk membantu dan mempermudah lulusan homeschooling lebih diakui di kalangan masyarakat.

Bagi penelitian lebih lanjut Hendaknya penelitian ini bisa menjadi bahan kajian lebih lanjut dalam upaya merumuskan homeschooling yang efektif baik dari segi perencanaan pembelajaran, pelaksanaan pembelajaran, evaluasi pembelajaran serta aspek-aspek yang meningkatkan mutu lulusan homeschooling. Temuan ini dapat dijadikan bahan perbandingan, bahan masukan atau melakukan kajian lebih lanjut pada lingkup yang lebih luas dan tingkat pendidikan alternatif yang berbeda. Penilitian ini juga bisa diaplikasikan pada penelitian homeschooling yang lain.

\section{DAFTAR PUSTAKA}

Arikunto, S. (1990). Organisasi dan administrasi: Pendidikan teknologi dan kejuruan. Jakarta: Rajawali Pers.

Arikunto, S. (2005). Manajemen penelitian. Jakarta: Rineka Cipta.

Miles, M. B., Huberman, A. M., \& Saldaña, J. (2014). Qualitative data analysis: A methods sourcebook. Los Angeles: Sage.

Muhtadi, A. (2014). Pendidikan dan pembelajaran di sekolah rumah (Homeschooling). Suatu tinjauan teoritis dan praktis. Yogyakarta. Retrieved from http://staff.uny.ac.id/sites/default/files/ 132280878/11. Pendidikan dan pembelajaran di sekolah rumah (home schooling)-tinjauan teoritis dan praktis.pdf

Mulyadi, S. (2007). Home schooling keluarga Kak Seto: mudah, murah, meriah, dan direstui pemerintah. Bandung: Kaifa PT Mizan Pustaka.

Sihombing, U. (1999). Pendidikan luar sekolah : kini dan masa depan. Mahkota.

Sudjana, D. (Djudju). (2001). Pendidikan luar sekolah: wawasan, sejarah perkembangan, falsafah Eamp; teori pendukung, serta asas. Falah Production.

Sumardiono. (2007). Homeschooling a leap for better learning: Lompatan cara belajar. Jakarta: Elex Media Komputindo. Retrieved from http://103.28.21.22/Record/IOS3NADAR-06090000022210

Sutinah. (2011). Metode penelitian sosial berbagai alternatif pendekatan (Edisi Revisi). Jakarta: Prenada Media Group. 